\title{
The acquisition of an insulin-secreting phenotype by HGF-treated rat pancreatic ductal cells (ARIP) is associated with the development of susceptibility to cytokine-induced apoptosis
}

\author{
E Anastasi, C Santangelo ${ }^{1}$, A Bulotta ${ }^{2}$, F Dotta, B Argenti ${ }^{3}$, C Mincione ${ }^{3}$, A Gulino ${ }^{3}$, \\ M Maroder ${ }^{3}, \mathbf{R}$ Perfetti $^{2}$ and U Di Mario \\ Department of Clinical Sciences, University 'La Sapienza', Rome, Italy \\ ${ }^{1}$ National Centre for Food Quality and Risk Assessment, Section of Nutrition, Istituto Superiore di Sanità, Rome, Italy \\ ${ }^{2}$ Division of Endocrinology and Metabolism, Cedars-Sinai Medical Center, University of California, Los Angeles, CA, USA \\ ${ }^{3}$ Department of Experimental Medicine and Pathology, University 'La Sapienza', Rome, Italy
}

(Requests for offprints should be addressed to E Anastasi; Email: emanuela.anastasi@uniroma1.it)

\begin{abstract}
The elucidation of mechanisms regulating the regeneration and survival of pancreatic beta cells has fundamental implications in the cell therapy of type 1 diabetes. The present study had the following three aims: 1 . to investigate whether pancreatic ductal epithelial cells can be induced to differentiate into insulin-producing cells by exposing them to hepatocyte growth factor (HGF); 2. to characterize some of the molecular events leading to their differentiation toward a beta-cell-like phenotype; 3 . to evaluate the susceptibility of newly differentiated insulin-secreting cells to cytokine-induced apoptosis, a mechanism of beta-cell destruction occurring in type 1 diabetes. We demonstrated that HGF-treated rat pancreatic ductal cell line (ARIP) cells acquired the capability to transcribe the insulin gene and translate its counterpart protein. HGF-treated cells also exhibited a glucose-dependent capability to secrete insulin into the cultured medium. Expression analysis of some of the genes regulating pancreatic beta-cell differentiation revealed a time-dependent transcription of neurogenin-3 and Neuro-D in response to HGF. Finally, we determined the susceptibility to proinflammatory cytokine (PTh1)-induced apoptosis by incubating HGF-treated and untreated ARIP cells with a cocktail of interleukin-1 beta (IL-1 $\beta$ ), tumor necrosis factor-alpha (TNF- $\alpha$ ) and interferon-gamma (IFN- $\gamma$ ). Such treatment induced apoptotic death, as determined by the TUNEL technique, in about $40 \%$ of HGF-treated, insulin-secreting ARIP cells, while untreated ARIP cells were resistant to PTh1-induced apoptosis. In conclusion, we showed that HGF promotes the differentiation of ARIP cells into pancreatic beta-cell-like cells, and that the differentiation toward an insulin-secreting phenotype is associated with the appearance of susceptibility to cytokine-induced apoptosis.
\end{abstract}

Journal of Molecular Endocrinology (2005) 34, 367-376

\section{Introduction}

Type 1 diabetes is an autoimmune disease characterized by the progressive and selective destruction of pancreatic beta cells (Wucherpfennig \& Eisenbarth 2001, Yoon \& Jun 2001). Factors other than autoimmunity may play a crucial role in the progression of the disease, such as an impaired balance between the rate of immune-mediated apoptotic phenomena and the capability of the pancreas to regenerate and expand the beta cell mass after damage (Risbud \& Bhonde 2002). The process of islet cell regeneration leads, after an initial phase of cell replication, to the acquisition of a number of phenotypic features that are characteristic of differentiated insulinproducing cells (Hardikar 2004). However, whether such a phenomenon of islet cell neogenesis and tissue repair is coupled to the acquisition of additional phenotypic characteristics, such as the ability to start and execute the apoptotic program in response to environmental stimuli, is presently unknown. A number of growth factors have been shown to be involved in the neogenesis of endocrine cells. In particular, a role for hepatocyte growth factor (HGF) and its receptor, in pancreas embryonal development (Sonnenberg et al. 1993, Calvo et al. 1996), as well as in beta-cell regeneration in autoimmmune diabetes (Bulotta et al. 2001), has been demonstrated. The in vivo beta-cell neogenetic process can be recapitulated in vitro, as beta-cell precursors and islet beta cells have been shown to proliferate and to differentiate toward an endocrine phenotype when stimulated with various growth factors (Hui et al. 2001, Nielsen et al. 2001, Brand et al. 2002, Egan et al. 2003). 
During embryonic life, one of the recently described major regulatory networks in the control of beta-cell development is represented by the Notch receptor/ ligand pathway (Apelqvist et al. 1999). Notch proteins belong to a conserved family of transmembrane receptors, including Notch 1 to 4 . Via interaction with a number of specific ligands (Delta-like 1 to 3 and Serrate 1 and 2), Notch receptors play a critical role in cell fate specification and in the control of cell growth and differentiation in a variety of cell lineages in vertebrates and invertebrates (Lewis 1998, Mumm \& Kopan 2000, Baron et al. 2002, Guidos 2002). A number of recent reports assessing knockout and transgenic mice for components of the Notch pathway suggest that Notch 1, via RBP-Jk- and HES-1-dependent downregulation of neurogenin-3 (ngn-3) and Neuro-D, either keeps enteroendocrine precursor cells in an undifferentiated state or drives them toward an exocrine fate (Apelqvist et al. 1999, Gradwohl et al. 2000, Schwitzgebel et al. 2000). Conversely, Notch 3 acts as an antagonist of Notch 1, thus promoting the beta-cell differentiation program (Apelqvist et al. 1999). Although the apoptotic program is linked to proliferation and differentiation processes in a number of tissues (reviewed in Medh \& Thompson 2000, Wagers et al. 2002), the acquisition of the apoptotic regulatory and execution machinery during beta-cell development remains to be investigated. Apoptosis is a mechanism of beta-cell death during immune-mediated damage, triggered by $\mathrm{T}$ cells and proinflammatory cytokines. Specifically, the proinflammatory cytokines interleukin-1 (IL-1), tumor necrosis factor-alpha (TNF- $\alpha$ ) and interferon-gamma (IFN- $\gamma$ ) play an important role in immune-induced damage of islet beta cells (Argiles et al. 1992, Corbett \& McDaniel 1992, Sandler et al. 1994, Rabinovitch \& Suarez-Pinzon 1998). We have previously demonstrated that Thl and proinflammatory cytokines (PThl) determine the apoptotic death of beta cells associated with downregulation of bcl-2 expression, and that the extent of apoptosis can be significantly reduced by the incubation of beta cells with Th2 cytokines (IL-10 and IL-4), thus indicating that cytokine signaling plays a major role in determining the death or survival of islet cells during inflammation (Marselli et al. 2001).

In order to identify a possible link between beta-cell neogenesis and susceptibility to apoptosis, we described here the ability of HGF to differentiate rat pancreatic ductal epithelial cells into insulin-producing cells. We demonstrated that the acquisition of beta-cell-like phenotype is associated with the expression of ngn- 3 and Neuro-D, the two chief transcription factors involved in the regulation of beta-cell differentiation during embryogenesis in man and other vertebrates (Apelqvist et al. 1999, Gradwohl et al. 2000, Schwitzgebel et al. 2000). Such an HGF-induced differentiation is associated with a newly acquired susceptibility of cells to undergo apoptosis when exposed to cytokines. The elucidation of the molecular events responsible for the acquisition of susceptibility to apoptosis during beta-cell neogenesis might lead to the identification of intervention strategies to uncouple the two processes, thereby re-establishing a favorable balance between the neogenetic beta-cell expansion and the autoimmune cell damage by inhibiting the apoptotic response.

\section{Materials and methods}

\section{Cell culture}

The rat pancreatic ductal cell line (ARIP) and HepG2 hepatoma cell line were gifts from the Diabetes Research Laboratories at Cedars-Sinai Medical Center, Los Angeles, CA, USA, respectively. ARIP cells were cultured in F12 medium (Gibco, BRL, Gaithersburg, MD, USA) containing 10\% fetal bovine serum (FBS) (Gibco), $50 \mu \mathrm{g} / \mathrm{ml}$ streptomycin, $100 \mu \mathrm{g} / \mathrm{ml}$ penicillin at $37^{\circ} \mathrm{C}$ under a humidified condition of $95 \%$ air, and $5 \%$ $\mathrm{CO}_{2}$. Hep-G2 cells were cultured in Minimum Alpha Essential Medium (Gibco, BRL) supplemented with FBS and antibiotics, as indicated for F12 medium. The glucose concentration in the culture medium was $12 \mathrm{mmol} / \mathrm{l}$. Treatment of ARIP cells with human recombinant HGF (R \& D Systems, Minneapolis, MN, USA) was carried out with cells grown in serum containing medium to $80 \%$ confluence, after a 'wash-out' incubation for $6 \mathrm{~h}$ with serum-free medium. To evaluate the time course of response, ARIP were exposed to HGF (50 ng/ $\mathrm{ml}$ ) or vehicle alone for $0,12,24,36,48$ or $72 \mathrm{~h}$. To detect the presence of $c$-met receptor, ARIP cells were cultured in the absence of HGF. Susceptibility to cytokine-induced apoptosis was analyzed by incubating untreated and HGF-treated ARIP cells $(50 \mathrm{ng} / \mathrm{ml}$ ) for $72 \mathrm{~h}$ in the presence or absence of human recombinant IL-1 $\beta$ (50 U/ml), TNF- $\alpha(1000 \mathrm{U} / \mathrm{ml})$ and IFN- $\gamma(1000$

$\mathrm{U} / \mathrm{ml}$ ) (Roche Diagnostics, Mannheim, Germany).

\section{Immunofluorescence microscopy}

ARIP cells were grown in monocoated chamber slides (Nange Nunc International, Naperville, IL, USA) in the presence or absence of HGF $(50 \mathrm{ng} / \mathrm{ml})$ for $0,12,24$, 36, 48, and $72 \mathrm{~h}$. For the detection of c-met, ARIP cells, as well as HEP-G2 cells, were grown in serum containing medium to approximately $80 \%$ confluence in the absence of HGF. Cells were washed in PBS and fixed with paraformaldehyde $4 \%$ (Sigma) for $30 \mathrm{~min}$ at $37^{\circ} \mathrm{C}$ in PBS. After three washings in PBS, the cells were permeabilized with $0 \cdot 1 \%(\mathrm{v} / \mathrm{v})$ of Triton X-100 in PBS for $10 \mathrm{~min}$. Cells were then incubated sequentially with 10\% normal blocking serum in PBS (rabbit or goat normal serum; Santa Cruz Biotechnology, San Diego, CA, USA) for $20 \mathrm{~min}$, followed by overnight incubation 
with guinea pig anti-porcine insulin antibody (Dako, Glostrup, Denmark) at a dilution of 1:100, or with rabbit polyclonal antihuman c-met (Met H-190, sc-8307; Santa Cruz Biotechnology) $(1: 25)$ at $4{ }^{\circ} \mathrm{C}$ in a humid chamber. After three washes in PBS, the cells were incubated with FITG-conjugated rabbit anti-guinea pig immunoglobulin (Ig) G (Dako) (1:40) for insulin detection, and goat antirabbit IgG (Chemicon, Temecula, CA, USA) (1:50) for $c$-met detection. The secondary antibody incubations were $1 \mathrm{~h}$ at room temperature in a humid chamber. Slides were mounted in DAPI fluorescent mounting medium (Vector Laboratory, Peterborough, UK) and examined under a fluorescent microscope (Olympus AX-70). Images were captured by Apogee Digital Camera and processed by Image-Pro computer software (Media Cybernetics, San Diego, CA, USA). Staining for insulin and for c-met was repeated at least three times, using independent cell cultures.

\section{Immunoprecipitation and immunoblotting}

Cells were washed twice with cold PBS and lysed in $500 \mu \mathrm{l}$ M-PER lysis buffer (Pierce, Ruckford, IL, USA) containing protein inhibitors $(1 \mathrm{mM}$ phenylmethylsufonyl fluoride, $8 \cdot 3 \mu \mathrm{M}$ aprotinin, $50 \mu \mathrm{M}$ leupeptin and $30 \mathrm{mM}$ sodium orthovanadate) (Sigma), and spun at $90000 \boldsymbol{g}$ for $5 \mathrm{~min}$ at room temperature (RT). The lysate was collected and centrifuged at $13000 \boldsymbol{g}$ for $5 \mathrm{~min}$ at $4{ }^{\circ} \mathrm{C}$. The whole-cell lysate was precleared by adding $1 \mu \mathrm{g}$ control IgG (Santa Cruz Biotechnology) together with $20 \mu \mathrm{l}$ resuspended volume of protein $\mathrm{G}$ agarose conjugate (Santa Cruz Biotechnology) at $4{ }^{\circ} \mathrm{C}$ for $30 \mathrm{~min}$. The protein concentration was then measured in the supernatant at least twice with protein assay reagent (Bio-Rad). Soluble proteins (200-500 $\mu \mathrm{g}$ ) were incubated overnight at $4{ }^{\circ} \mathrm{C}$ on a rotating device with $1 \mu \mathrm{g}$ antihuman met (Met H-190, sc-8307; Santa Cruz Biotechnology) and $50 \mu \mathrm{l}$ protein $\mathrm{G}$ agarose conjugate. The beads were washed with $10 \%$ M-Per in PBS, and the pellet was resuspended in $30 \mu \mathrm{l}$ electrophoresis sample buffer for immunoblotting. For immunoblotting, precipitated proteins were separated on $7 \cdot 5 \%$ SDS polyacrylamide gels and transferred to a nitrocellulose membrane (Bio-Rad). The transferred membranes were soaked in Poinceau-S solution (Sigma) to check that comparable amounts of proteins were loaded on the gel and to check the homogeneity of the transfer. After blocking from nonspecific binding with 3\% bovine serum albumin in PBS-Tween 20 (Sigma) for $1 \mathrm{~h}$ at RT, the membranes were immunoblotted with antihuman c-met (Met H-190, sc-8307; Santa Cruz Biotechnology) (1:500) overnight at $4^{\circ} \mathrm{C}$ on a rotating device. After three washes in PBS-Tween 20, the membranes were incubated with the secondary antibody conjugated with horseradish peroxidase for $1 \mathrm{~h}$ at RT. Immunoreactive proteins were visualized by the
ECL immunodetection system (Amersham, Arlington Heights, IL, USA).

\section{Measurement of insulin release}

ARIP cells were plated at a density of $10^{6}$ cells/well in a six-well plate. Glucose-dependent secretion of insulin was evaluated in ARIP cells cultured in the presence or absence of HGF ( $50 \mathrm{ng} / \mathrm{ml}$ added every $8 \mathrm{~h}$ ) for $60 \mathrm{~h}$. Cells were kept in $5.5 \mathrm{mM}$ glucose until the day of the experiment and then either challenged with $20 \mathrm{mM}$ glucose or re-exposed to $5.5 \mathrm{mM}$ glucose, for $60 \mathrm{~min}$. The level of insulin in the culture medium was measured by RIA (Linco Research, St. Charles, MO, USA) and normalized for the total cellular protein content detected in the pellet of each individual culture, as measured by the Bradford method (Bio-Rad).

\section{RT-PCR}

The expression of mRNA encoding for Notch, ngn-3 and Neuro-D was evaluated by RT-PCR in four separate experiments. RT-PCR was performed by a first step of reverse transcription from DNase I-treated total RNA isolated from ARIP cells, followed by PCR, essentially as previously described (Felli et al. 1999) with a Gene-Amp RNA PCR kit (Perkin-Elmer Cetus, Norwalk, GT, USA). Samples of PGR reactions were taken at different cycles throughout the amplification, allowing accurate quantitation of the product during the exponential phase of DNA amplification. Negative controls included RT-PCR without reverse transcriptase or without RNA. Amplification of beta-actin with 5'-GTGGGCGGCTCTAGGCACCAA-3' and 5'-CTC TTTGATGTCAGGCACGA TTTC- $3^{\prime}$ as $5^{\prime}$ and $3^{\prime}$ primers was used as an internal control for both reverse transcription and PCR, and as a measure of the relative amount of RNA. Amplifications of Notch 3 cDNAs were performed at an annealing temperature of $55^{\circ} \mathrm{C}$ with the following primers: $5^{\prime}$ - CAGGACAGCAAGGAGGA GAC-3' , forward; 5'-GTG ATCTGTGATCTC CG GGT-3', reverse (rat Notch 3 sequence). Amplification of ngn-3 cDNA was performed with the 5'-CAG CAACGCTTTCGCGGAG-3' forward and 5'-TCAGT GCGAACTCGCTCTTG-3' reverse primers (rat ngn-3 sequence). Amplification of Neuro-D cDNA was performed with the 5'-CTTGGGCAAGAACTATAT CTGG-3' forward and 5'-GGAGTAGGGATGCACG GGGAA-3' reverse primers (rat Neuro-D). The hybridizations were performed with a specific oligomer internal to the amplified sequences. Semiquantitative analysis was performed by densitometric gel scanning with the Gel Doc 2000 video image system (Bio-Rad). The expression of insulin (INS), GLUT2, glucokinase (GK), IL- $1 \beta$, TNF- $\alpha$ and IFN- $\gamma$ receptors was evaluated by RT-PCR with the following primers: (INS) forward 
5'-CCT GCG CAG GCT TTT GTC AA-3' and reverse 5'-CTC CAG TGG CAA GGT CTG AA-3'; (GLUT2) forward 5'-CTG TAC TGT GGG CTA ATT TCA GG-3' and reverse 5'-GGT GAA CTT ATC CAG CAA CAG C-3'; (GK) forward 5'-GCG GAG ATG CTC TTT GAC TAC-3', reverse 5'- GCG GAG ATG CTC TTT GAC TAC-3' and reverse 5'-CAG TGG CGA CAA TGA TGG-3'; (IL-1R) forward 5'-GCT GGA GAG TAC TCT TCA TGG TG 3' and reverse 5'-GAT GAA TGG TGG AGT CGT TGT CG-3'; (TNF-RI) forward 5'-AGG AAG TGG CAC AAA GGA ACG-3' and reverse 5'-TAG ACA CGG TGT TCT GTT TCT CG-3'; (IFN- $\gamma$-R) forward 5'-CGT AAG GTC AAT GTG AGT CAG G-3' and reverse 5'-GAA GAG AAG AGG AGG AAC AAG C-3'. All PGR products were electrophoresed on agarose gel and the bands visualized by ethidium bromide staining.

\section{Evaluation of apoptosis}

Untreated and HGF-treated ARIP cells were grown in monocoated chamber slides and treated with cytokines as described above. The presence of apoptotic cells was determined by propidium iodide (PI) staining and TUNEL assay (In Situ Cell Death Detection System; Roche Diagnostics), according to the manufacturer's instructions. Briefly, cells were fixed with $4 \%$ formaldeyde/PBS for $25 \mathrm{~min}$ at $4{ }^{\circ} \mathrm{C}$, washed in PBS and permeabilized with prechilled $0.2 \%$ Triton X-100/ PBS for $5 \mathrm{~min}$ on ice. After two washes with PBS, cells were covered with terminal deoxynucleotidyl transferase (TdT) buffer containing TdT enzyme and fluorescindUTP, and the slides were incubated in a humidified chamber at $37{ }^{\circ} \mathrm{C}$ for $60 \mathrm{~min}$. A TdT-minus negative control was performed by replacing the TdT enzyme with deionized $\mathrm{H}_{2} \mathrm{O}$. The reaction was terminated by immersing slides in $2 \mathrm{SSC}$ for $15 \mathrm{~min}$ at RT. The slides were then washed twice in PBS and the cells stained with $10 \mathrm{ng} / \mathrm{ml}$ propidium iodide (PI)/PBS at room temperature for $10 \mathrm{~min}$. After two washes in deionized $\mathrm{H}_{2} \mathrm{O}$, slides were mounted in DAPI fluorescent mounting medium (Vector Laboratory) and examined under a fluorescent microscope (Olympus AX-70). Results were expressed as means \pm S.D. Statistical analysis was performed by Student's $t$-test.

\section{Results}

\section{The $c$-met ligand, HGF, induces the pancreatic ductal ARIP cell line to differentiate into insulin-producing beta-like cells}

Recent studies indicated that treatment of ARIP cells with GLP-1 resulted in their differentiation into insulin-producing and -secreting cells (Hui et al. 2001).
These cells could thus represent a valuable in vitro model to study pancreatic islet neogenesis. When analyzed by immunofluorescence, cultured ARIP cells were shown to express a significant amount of c-met receptor protein (Fig. 1A). In contrast, no c-met positive staining was detected when the primary antibody was omitted and the cells were incubated solely with the secondary antibody. The expression of c-met protein was also demonstrated by immunoprecipitation and Western blotting of ARIP cell lysates (Fig. 1B). As shown in Fig. 1B, both the $170 \mathrm{kDa}$ single-chain precursor and the $145 \mathrm{kDa}$ beta subunit of the receptor were detected. Treatment with HGF $(50 \mathrm{ng} / \mathrm{ml})$ induced the differentiation of ARIP ductal epithelial cells into insulinexpressing cells. As shown in Fig. 2, no insulin immunoreactivity was observed prior to the exposure of cells to HGF (time 0 ) or in cells cultured in the presence of vehicle alone (control $72 \mathrm{~h}$ ). Insulin was first detected after $12 \mathrm{~h}$ of HGF treatment. By day 3 of HGF treatment, the number of insulin-expressing cells was sevenfold above basal condition $(68 \cdot 3 \pm 7 \cdot 0$, mean \pm S.E. for three individual experiments). HGF-differentiated insulinproducing cells express GLUT2 and glucokinase (GK) (Fig. 2, lower panel) and can also secrete insulin in a glucose-dependent fashion (Fig. 3). Indeed, cells cultured in the presence of HGF and challenged to high glucose concentration $(20 \mathrm{mM})$ secrete higher amounts of insulin than cells exposed to low glucose medium $(5.5 \mathrm{mM})$.

\section{ngn-3 and Neuro-D are upregulated during HGF-induced beta-cell differentiation}

As Notch-3 receptor and its downstream effectors ngn-3 and Neuro-D have been found to be critical for endocrine pancreas differentiation, we investigated their expression during HGF-induced differentiation of pancreatic ductal cells into insulin-producing cells. Notch 3 was present in untreated ARIP cells, and its level did not vary during the process of cell differentiation. The expression of ngn-3 and Neuro-D was instead modulated during differentiation. ngn-3 became detectable $6 \mathrm{~h}$ after the beginning of HGF treatment, reaching a maximum after $10 \mathrm{~h}$ and then diminishing to become undetectable after $24 \mathrm{~h}$. The effect of HGF on the expression of Neuro-D was delayed when compared with ngn-3, becoming detectable $12 \mathrm{~h}$ after the beginning of treatment, with a peak after $24 \mathrm{~h}$ followed by a slow decline (although still detectable) after 72 h (Fig. 4).

\section{HGF-differentiated ductal cells undergo apoptosis in response to proinflammatory cytokines}

TUNEL staining revealed that untreated ARIP cells were resistant to cytokine-induced damage, apoptotic phenomena affecting very few cells, whereas cell death 
A

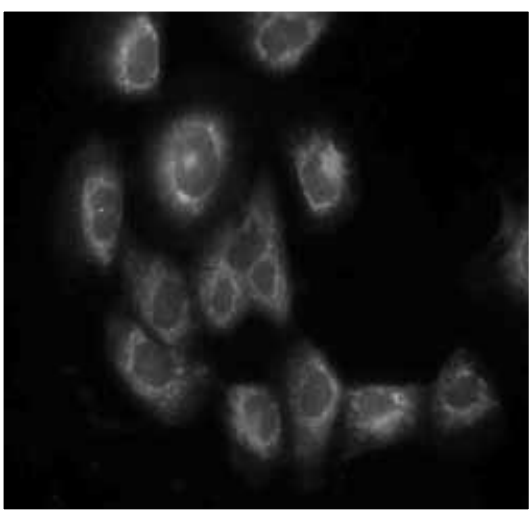

ARIP

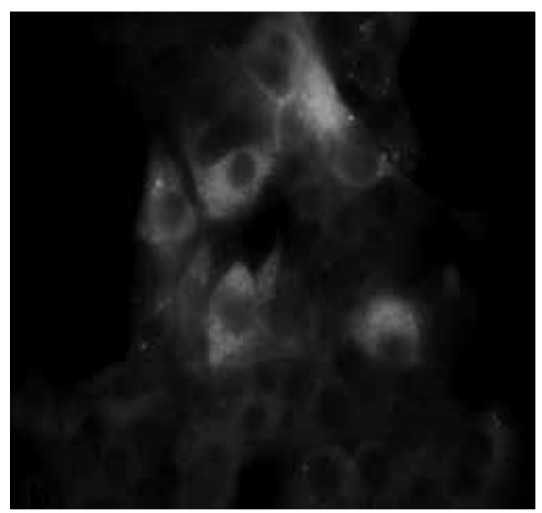

HEPG2

B

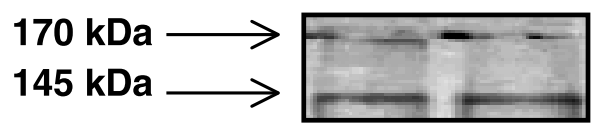

\section{ARIP HEPG2}

Figure 1 (A) Immunocytochemistry for c-met. ARIP cells were cultured for $24 \mathrm{~h}$ in $\mathrm{F} 12$ medium containing serum and then incubated for $6 \mathrm{~h}$ with serum-free medium (left panel). The HepG2 (hepatoma) cell line was used as positive control (right panel). Both ARIP and HepG2 cells stained solely with secondary antibody were used as negative control (Magnification: $\times 40$ ). (B) Western blot analysis of $c$-met. ARIP cells were cultured for $24 \mathrm{~h}$ in $\mathrm{F} 12$ medium containing serum and then incubated for $6 \mathrm{~h}$ with serum-free medium. Total cell lysates were immunoprecipitated with antihuman c-met antibody and resolved on $7.5 \%$ polyacrylamide gel. Total cell lysates of HepG2 cell line (hepatoma) immunoprecipitated with the same antihuman $c$-met antibody were used as positive control. Arrows indicate the $170 \mathrm{kDa}$ single-chain precursors and the $145 \mathrm{kDa}$ the beta subunit of the receptor.

was dramatically induced in HGF-treated insulinsecreting cells cultured with a cocktail of proinflammatory cytokines, including IL- $1 \beta(50 \mathrm{U} / \mathrm{ml}), \mathrm{TNF}-\alpha(1000$ $\mathrm{U} / \mathrm{ml})$ and IFN- $\gamma(1000 \mathrm{U} / \mathrm{ml})$. By this technique, apoptotic cells were identified by yellow, highly condensed and/or fragmented nuclei; the yellow emission of fluorescence was due to the overlay of TUNEL-positive (green) and PI-positive (red) staining (Fig. 5b). The percentage of apoptotic cells (calculated as number of apoptotic cells/apoptotic + non-apoptotic cells $\times 100)$ was $6 \cdot 3 \pm 1 \cdot 8 \%$ in undifferentiated ARIP cells treated with proinflammatory cytokines, and increased by up to $40 \cdot 3 \pm 7 \cdot 9 \%$ in cytokine-exposed HGF-treated cells $(P<0 \cdot 001$, Student's $t$-test $)$.

\section{Discussion}

The differentiation of pancreatic beta cells requires the coordinated action of multiple signaling molecules. We used ductal derived ARIP cells as an in vitro model to investigate the role of extracellular and intracellular factors regulating the neogenesis and survival of newly differentiated beta cells. In the present study, we demonstrated that treatment of pancreatic ductal cells with HGF promoted their differentiation into insulinsecreting cells. Such an ability of HGF to promote beta-cell terminal differentiation extends the spectrum of activities of this growth factor, previously shown to induce in vivo and in vitro differentiation of beta cells (Otonkoski et al. 1994a,b, 1996, García-Ocaña et al. 2000, Gahr et al. 2002). HGF has also been shown to increase in vitro the expression of Reg, a protein implicated in pancreatic regeneration (Anastasi et al. 1999, Kobayashi et al. 2000), and to convert, when administered alone or in combination with activin A, pancreatic acinar AR42J cells into insulin-producing cells (Mashima et al. 1996). Additionally, the capacity of HGF to induce the differentiation of a ductal cell line 


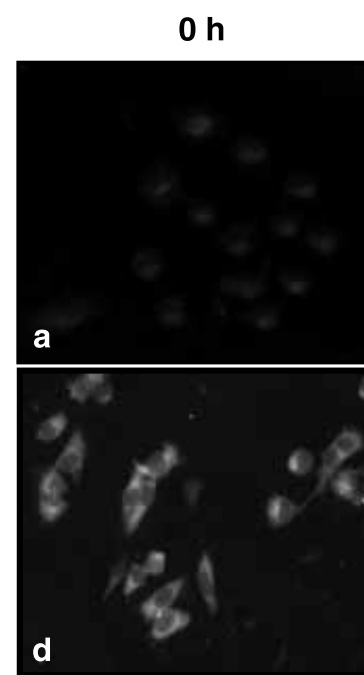

$48 \mathrm{~h}$

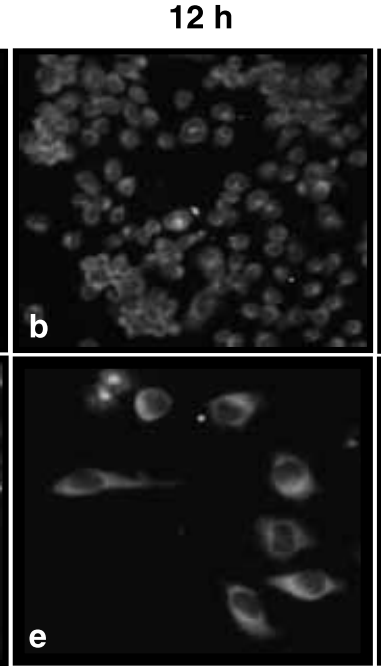

$72 \mathrm{~h}$

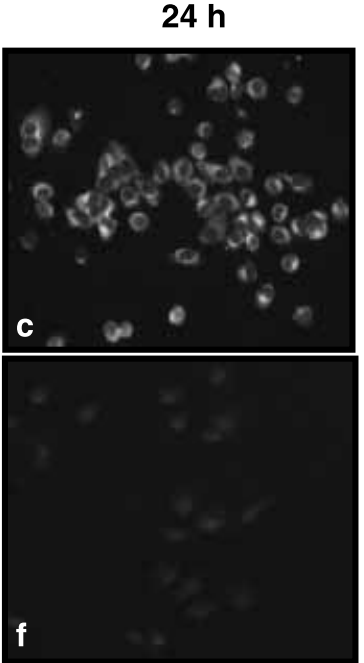

Control $72 \mathrm{~h}$

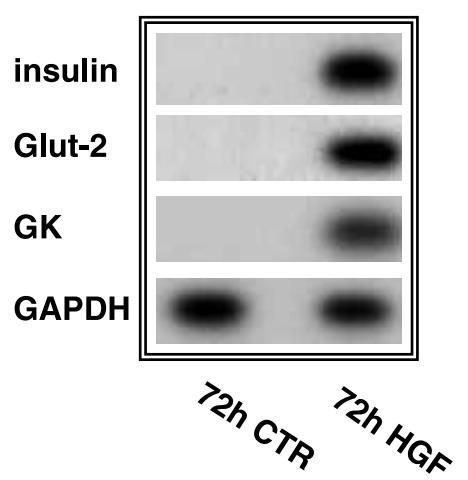

Figure 2 (Upper panel) Immunocytochemistry for insulin of ARIP cells cultured with HGF $(50 \mathrm{ng} / \mathrm{ml})$, or vehicle alone, for $0-72 \mathrm{~h}$. This experiment was repeated three times, providing results very similar to the one depicted here. Pictures were taken at $\times 20$ magnification. Panel e shows a greater magnification. (Lower panel) Expression of insulin, GLUT-2 and glucokinase (GK) and the endogenous control GAPDH evaluated by RT-PCR, using specific primers, in untreated and in cells treated with HGF $(50 \mathrm{ng} / \mathrm{ml})$ for $72 \mathrm{~h}$.

(ARIP) into insulin-producing cells suggests that this growth factor may be able to recapitulate, at least in part, the neogenetic process that leads from the cell expansion of precursor cells to the terminal differentiation of insulin-producing cells. Indeed, pancreatic ductal cells are known to give rise to pancreatic endocrine cells both during pancreatic organogenesis and islet cell neogenesis after pancreatic injury in adult animals (Teitelman \& Lee 1987, Bonner-Weir et al. 1993, Bouwens 1998). During pancreas organogenesis, the Notch pathway and downstream signals act as crucial determinants of cell growth and differentiation, directing the cell fate toward either a differentiated endocrine phenotype or a progenitor-like characteristic
(Edlund 2002). Among the members of Notch protein family, Notch 3 has been shown to promote the beta-cell differentiation program (Apelqvist et al. 1999) through the modulation of ngn-3 and Neuro-D, which in turn promote beta-cell terminal differentiation. We demonstrated that ngn-3 and Neuro-D genes were expressed in epithelial ductal cells in response to HGF exposure. It is worth noting that a time-dependent course of the expression of both genes could be demonstrated during differentiation. In fact, ngn-3 was the first protein to be measurable after the beginning of HGF treatment, followed by a plateau and then a progressive decline until it became undetectable at $24 \mathrm{~h}$. The effect of HGF on the expression of Neuro-D was slightly delayed when 


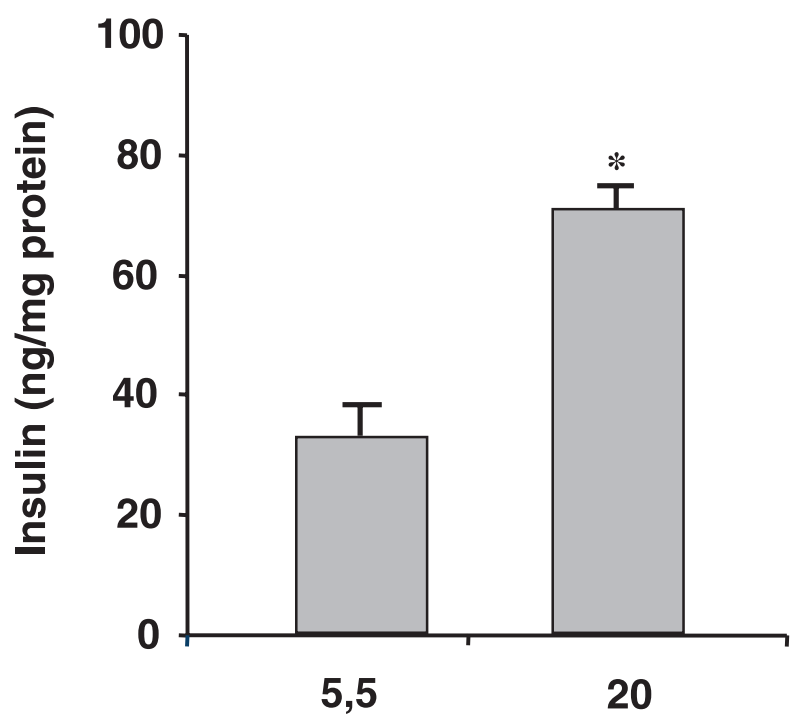

Glucose (mM)

Figure 3 Glucose-dependent secretion of insulin evaluated in ARIP cells cultured in the presence or absence of HGF $(50 \mathrm{ng} / \mathrm{ml})$ for $60 \mathrm{~h}$. Cells were kept in $5.5 \mathrm{mM}$ glucose until the day of the experiment and then challenged with either $20 \mathrm{mM}$ glucose or re-exposed to $5.5 \mathrm{mM}$ for $1 \mathrm{~h}$. Each experiment was repeated at least three times, data are means \pm S.D. ${ }^{*} P<0.01$ (Student's $t$-test).

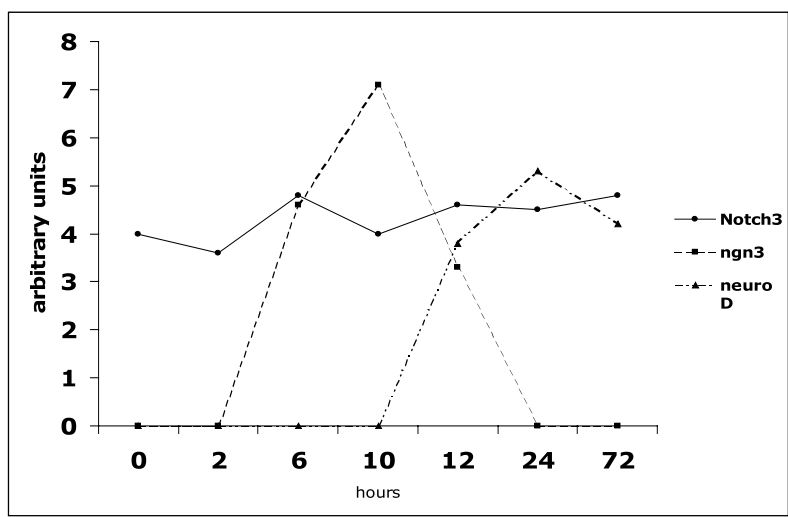

Figure 4 Time course of Notch 3 , ngn-3 and Neuro-D gene expression in ARIP cells cultured with HGF $(50 \mathrm{ng} / \mathrm{ml})$ from 0 to $72 \mathrm{~h}$. The expression of Notch 3 , ngn-3 and Neuro-D was evaluated by RT-PCR of total RNAs. Notch 3 , ngn-3 and Neuro-D amplified products are represented as the densitometric analysis of autoradiographic bands normalized to beta-actin amplified products evaluated at the same times. Results shown represent one point of the multiple samples taken during the exponential phase of DNA amplification for appropriate quantitation, as described in Materials and methods. Results depicted represent three similar experiments (differing less than $20 \%$ from each other).

compared with the expression of ngn-3, reaching a peak after $24 \mathrm{~h}$, and being still detectable $72 \mathrm{~h}$ after the beginning of HGF treatment.
The expression profile of the those two transcripts, as detected in the experimental model described in the present report, was very similar to what has been shown to happen during pancreatic development. Indeed, during pancreatic organogenesis, the expression of ngn-3, after reaching a peak during the major wave of endocrine cell genesis, greatly diminishes until it becomes virtually absent in the adult pancreas. In the same process, Neuro-D is expressed slightly later than ngn-3, and, unlike ngn-3, its expression persists in adult islet cells, where it modulates the expression of various genes, including insulin (Wilson et al. 2003, Chakrabarti \& Mirmira 2003). Our observation that rat ductal cells constitutively express Notch 3 receptor agrees with previous results obtained in human ductal cells (Heremans et al. 2002). However, whereas the HGFinduced beta-cell differentiation process is associated with an upregulation of ngn-3 and Neuro-D gene expression, such a process does not result in any change in the expression level of the Notch 3 receptor.

Beta-cell mass is physiologically kept in balance between neogenesis and apoptosis, and this balance is impaired in type 1 diabetes. We here show that the acquisition of susceptibility to apoptosis after exposure to IL-1 $\beta$, TNF- $\alpha$ and IFN- $\gamma$ is part of the HGF-induced beta-like terminal differentiation program. In type 1 diabetes, the impaired function and destruction of beta cells results from the direct contact with islet-infiltrating macrophages and $\mathrm{T}$ cells and/or exposure to inflammatory products of the islet-infiltrating cells, such as free radicals and cytokines. Specifically, in vitro studies have shown that inflammatory cytokines are capable of inducing apoptosis in purified primary human, rat and mouse beta cells (Delaney et al. 1997, Stassi et al. 1997, Rabinovitch \& Suarez-Pinzon 1998). In this study, we demonstrate that HGF treatment confers susceptibility to Th1 cytokine-induced apoptosis in ARIP cells, a cell line resistant to cytokine apoptotic stimuli in the basal condition. It is worth mentioning that, when characterized by RT-PCR for the presence of inflammatory cytokine receptors, ARIP cells were shown to express (in the basal condition, before being differentiated in insulin-producing cells by HGF) high levels of IL-1 $\beta$, TNF- $\alpha$ and IFN- $\gamma$ cytokine receptors, thus demonstrating the constitutive expression of those receptors independently of HGF exposure. We therefore suggest that the susceptibility to cytokine-induced apoptosis is strictly related to the differentiation process that modulates pathways or genes that would modify the cellular response to environmental stimuli.

Our results are consistent with studies performed with primary cultures of rat oligodendrocyte progenitor cells showing that, as cells differentiated, they become progressively more susceptible to cytokine-induced apoptosis. The authors have hypothesized that differential susceptibility is due to developmental changes in 
+HGF/-PTh1
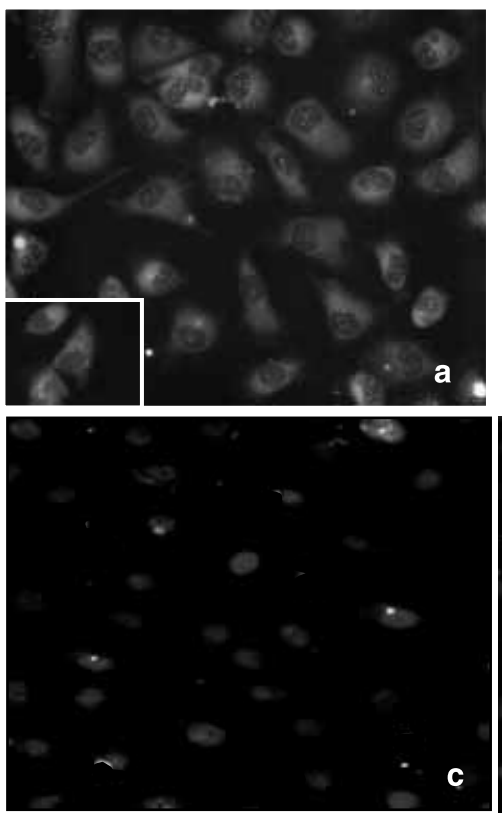

-HGF/-PTh1
+HGF+PTh1
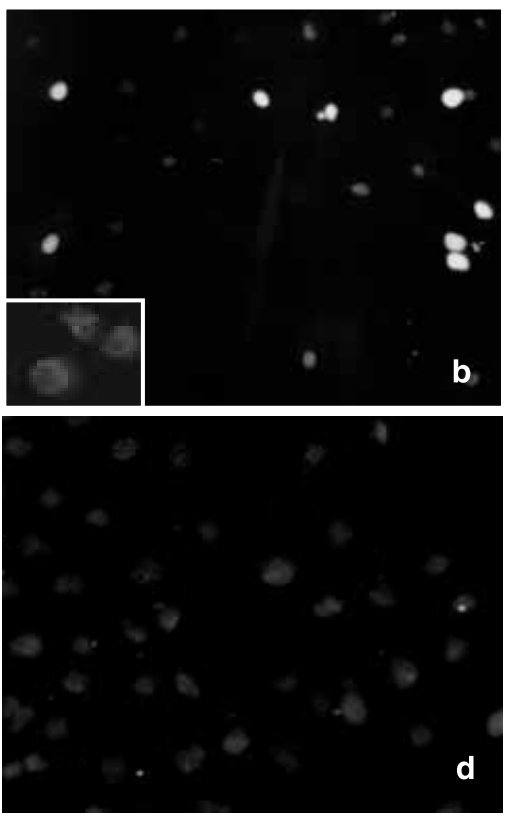
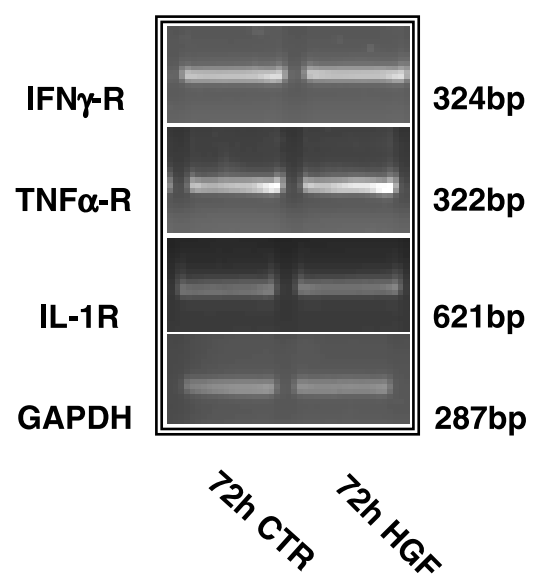

Figure 5 (Left panel) TUNEL detection of apoptotic ARIP cells. Untreated control (c and d) and HGF-treated (a and b) ARIP cells were cultured with or without a combination of IL-1 $\beta$ (50 U/ml), TNF- $\alpha(1000 \mathrm{U} / \mathrm{ml})$ and IFN- $\gamma(1000 \mathrm{U} / \mathrm{ml})$ proinflammatory cytokines (PTh1) for $72 \mathrm{~h}$. Apoptotic cells (b) are identified by highly condensed and/or fragmented nuclei. Similar results were obtained in three independent experiments $(P<0.001 \mathrm{vs}$ control ARIP cells incubated with proinflammatory cytokines). In the insets are represented a particular of the insulin-positive cells stained with DAPI (magnification: $\times 20)$. (Right panel) Expression of IL-1 $\beta$, TNF- $\alpha$ and IFN- $\gamma$ receptors, and the endogenous control GAPDH was evaluated by RT-PCR, in untreated and in HGF-treated cells $(50 \mathrm{ng} / \mathrm{ml})$ for $72 \mathrm{~h}$.

molecules involved in apoptotic signaling, having observed a shift of balance toward proapoptotic molecules (Osterhout et al. 2002). All these findings, taken together, suggest that death susceptibility is intrinsic to the differentiation state of the cell, and that this may render the mature cells very sensitive to apoptotic signals generated after injury or illness.

In summary, our data indicate that HGF promotes the differentiation of ARIP cells into a pancreatic beta-cell-like cell, as in the molecular events occurring in endocrine pancreas embryogenesis, and that the differentiation toward an insulin-secreting phenotype is associated with the appearance of susceptibility to cytokine-induced apoptosis. Our observations indicate that ARIP ductal cell lines differentiated by HGF may be a good model for the identification of those target genes that confer the susceptibility of beta-cell-like cells to cytokine-induced apoptosis. Moreover, these genes could counteract the benefits of beta-cell regeneration and, consequently, the success of transplantation strategies based on the use of stem and/or not fully differentiated endocrine cells. The recognition and characterization of these genes may direct future research to identify pharmacologic agents able selectively to suppress the expression of unwanted mRNAs.

\section{Acknowledgements}

We thank Sara Fallucca and Simona Chicarella for their technical assistance. This work was supported by grants from the Ministero della Salute and the Ministero dell'Università e della Ricerca.

\section{Funding}

The authors declare that there is no conflict of interest that would prejudice the impartiality of this scientific work.

\section{References}

Anastasi E, Ponte E, Gradini R, Bulotta A, Sale P, Tiberti C,

Okamoto H, Dotta F \& Di Mario U 1999 Expression of Reg and 
cytokeratin 20 during ductal cell differentiation and proliferation in a mouse model of autoimmune diabetes. European foumal of Endocrinology $141644-652$.

Apelqvist A, Li H, Sommer L, Beatus P, Anderson DJ, Honjo T, Hrabe de Angelis M, Lendahl U \& Edlund H 1999 Notch signalling controls pancreatic cell differentiation. Nature 26 877-881.

Argiles JM, Lopez-Soriano J, Ortiz MA, Pou JM \& Lopez-Soriano FJ 1992 Interleukin-1 and beta-cell function: more than one second messenger? Endocrine Reviews 13 515-524.

Baron M, Aslam H, Flasza M, Fostier M, Higgs JE, Mazaleyrat SL \& Wilkin MB 2002 Multiple levels of Notch signal regulation (review). Molecular Membrane Biology 19 27-38.

Bonner-Weir S, Baxter LA, Schuppin GT \& Smith FE 1993 A second pathway for regeneration of adult exocrine and endocrine pancreas: a possible recapitulation of embryonic development. Diabetes 42 1715-1720.

Bouwens L 1998 Transdifferentiation versus stem cell hypothesis for the regeneration of islet beta-cells in the pancreas. Microscopy Research and Technique 43 332-336.

Brand SJ, Tagerud S, Lambert P, Magil SG, Tatarkiewicz K, Doiron K \& Yan Y 2002 Pharmacological treatment of chronic diabetes by stimulating pancreatic beta-cell regeneration with systemic co-administration of EGF and gastrin. Pharmacology and Toxicology $91414-420$.

Bulotta A, Di Cesare E, Ponte E, Falchi M, Sciacchitano S, Cucinotta D, Taruscio D, Di Mario U \& Anastasi E 2001 Increased c-met expression during ductal beta cell neogenesis in experimental autoimmune diabetes. Growth Factors 19 259-267.

Calvo B, Boucher C, Pelletier G \& Morisset J 1996 Ontogeny of hepatocyte growth factor and $c$-met/HGF receptor in rat pancreas. Biochemical and Biophysical Research Communications 229 257-263.

Chakrabarti SK \& Mirmira RG 2003 Transcription factors direct the development and function of pancreatic $\beta$ cells. Trends in Endocrinology and Metabolism 2 78-84.

Corbett JA \& McDaniel ML 1992 Does nitric oxide mediate autoimmune destruction of beta-cells? Possible therapeutic interventions in IDDM. Diabetes 41 897-903.

Delaney CA, Pavlovich D, Hoorens A, Pipeleers DG \& Eizirik DL 1997 Cytokines induce deoxyribonucleic acid strand breaks and apoptosis in human pancreatic islet cells. Endocrinology 138 2610-2614.

Edlund H 2002 Pancreatic organogenesis - developmental mechanisms and implications for therapy. Nature Reviews Genetics 3 524-532.

Egan JM, Bulotta A, Hui H \& Perfetti R 2003 GLP-1 receptor agonists are growth and differentiation factors for pancreatic islet beta cells. Diabetes Metabolism Research and Reviews 19 115-123.

Felli MP, Maroder M, Mitsiadis TA, Campese AF, Bellavia D, Vacca A, Mann RS, Frati L, Lendahl U, Gulino A \& Screpanti I 1999 Expression pattern of notch1, 2 and 3 and Jagged 1 and 2 in lymphoid and stromal thymus components: distinct ligand-receptor interactions in intrathymic T cell development. International Immunology 11 1017-1025.

Gahr S, Merger M, Bollheimer LC, Hammerschmied CG, Schölmerich J \& Hügl SR 2002 Hepatocyte growth factor stimulates proliferation of pancreatic $\beta$-cells particularly in the presence of subphysiological glucose concentrations. Fournal of Molecular Endocrinology 28 99-110.

García-Ocaña A, Takane KK, Syed MA, Philbrick WM, Vasavada RC \& Stewart AF 2000 Hepatocyte growth factor overexpression in the islet of transgenic mice increases beta cell proliferation, enhances islet mass, and induces mild hypoglycemia. Fournal of Biological Chemistry 275 1226-1232.

Gradwohl G, Dierich A, LeMeur M \& Guillemot F 2000 Neurogenin 3 is required for the development of the four endocrine cell lineages of the pancreas. PNAS 97 1607-1611.

Guidos CJ 2002 Notch signaling in lymphocyte development. Seminars in Immunology 14 395-404.
Hardikar AA 2004 Generating new pancreas from old. Trends in Endocrinology and Metabolism 5 198-203.

Heremans Y, Van De Casteele M, Veld P, Gradwohl G, Serup P, Madsen O, Pipeleers D \& Heimberg H 2002 Recapitulation of embryonic neuroendocrine differentiation in adult human pancreatic duct cells expressing neurogenin 3. Fournal of Cell Biology 159 303-311.

Hui H, Wright C \& Perfetti R 2001 Glucagon-like peptide 1 induces differentiation of islet duodenal homeobox-1-positive pancreatic ductal cells into insulin-secreting cells. Diabetes 50 785-796.

Kobayashi S, Akiyama T, Nata K, Abe M, Tajima M, Shervani NJ, Unno M, Matsuno S, Sasaki H, Takasawa S \& Okamoto H 2000 Identification of a receptor for reg (regenerating gene) protein, a pancreatic beta-cell regeneration factor. Foumal of Biological Chemistry 275 10723-10726.

Lewis J 1998 Notch signaling and the control of cell fate choices in vertebrates. Seminars in Cell and Developmental Biology 9 583-589.

Marselli L, Dotta F, Piro S, Santangelo C, Masini M, Lupi R, Realacci M, del Guerra S, Mosca F, Boggi U, Purrello F, Navalesi R \& Marchetti P 2001 Th2 cytokines have a partial, direct protective effect on the function and survival of isolated human islets exposed to combined proinflammatory and Thl cytokines. Journal of Clinical Endocrinology and Metabolism $864974-4978$.

Mashima H, Shibata H, Mine T \& Kojima I 1996 Formation of insulin-producing cells from pancreatic acinar AR42J cells by hepatocyte growth factor. Endocrinology 137 3969-3976.

Medh RD \& Thompson EB 2000 Hormonal regulation of physiological cell turnover and apoptosis. Cell and Tissue Research 301 101-124.

Mumm JS \& Kopan R 2000 Notch signaling: from the outside in. Developmental Biology 228 151-165.

Osterhout DJ, Marin-Husstege M, Abano P \& Casaccia-Bonnefil P 2002 Molecular mechanisms of enhanced susceptibility to apoptosis in differentiating oligodendrocytes. Fournal of Neuroscience Research 69 24-29.

Otonkoski T, Beattie GM, Lopez AD \& Hayek A 1994a Use of hepatocyte growth factor/scatter factor to increase transplantable human fetal islet cell mass. Transplantation Proceedings 263334.

Otonkoski T, Beattie GM, Rubin JS, Lopez AD, Baird A \& Hayek A $1994 b$ Hepatocyte growth factor/scatter factor has insulinotropic activity in human fetal pancreatic cells. Diabetes $\mathbf{4 3}$ 947-953.

Otonkoski T, Cirulli V, Beattie M, Mally MI, Soto G, Rubin JS \& Hayek A 1996 A role for hepatocyte growth factor/scatter factor in fetal mesenchyme-induced pancreatic beta-cell growth. Endocrinology 137 3131-3139.

Rabinovitch A \& Suarez-Pinzon WL 1998 Cytokines and their roles in pancreatic islet beta-cell destruction and insulin-dependent diabetes mellitus. Biochemical Pharmacology 55 1139-1149.

Risbud MV \& Bhonde RR 2002 Models of pancreatic regeneration in diabetes. Diabetes Research and Clinical Practice 58 155-165.

Sandler S, Eizirik DL, Sternesjo J \& Welsh N 1994 Role of cytokines in regulation of pancreatic B-cell function. Biochemical Society Transactions 22 26-30.

Schwitzgebel VM, Scheel DW, Conners JR, Kalamaras J, Lee JE, Anderson DJ, Sussel L, Johnson JD \& German MS 2000 Expression of neurogenin3 reveals an islet cell precursor population in the pancreas. Development 127 3533-3542.

Sonnenberg E, Meyer D, Weidner KM \& Birchmeier C 1993 Scatter factor/hepatocyte growth factor and its receptor, the $c$-met tyrosine kinase, can mediate a signal exchange between mesenchyme and epithelia between during mouse development. Journal of Cell Biology $1223-235$.

Stassi G, Maria RD, Rudert W, Testi R, Galluzzo A, Giordano C \& Trucco M 1997 Nitric oxide primes pancreatic b-cells for Fas-mediated destruction in insulin-dependent diabetes mellitus. Journal of Experimental Medicine 186 1193-1200. 
Teitelman G \& Lee JK 1987 Cell lineage analysis of pancreatic islet development: glucagon and insulin cells arise from catecholaminergic precursors present in the pancreatic duct. Developmental Biology 121454466.

Wagers AJ, Christensen JL \& Weissman IL 2002 Cell fate determination from stem cells. Gene Therapy 9 606-612.

Wilson ME, Scheel D \& German MS 2003 Gene expression cascade in pancreatic development. Mechanisms in Development 120 65-80.
Wucherpfennig KW \& Eisenbarth GS 2001 Type 1 diabetes. Nature Immunology 2 767-768.

Yoon JW \& Jun HS 2001 Cellular and molecular pathogenetic mechanisms of insulin dependent diabetes mellitus. Annals of the New York Academy of Sciences 928 200-211.

Received 22 November 2004

Accepted 13 December 2004 